Fidei: Jurnal Teologi Sistematika dan Praktika, Vol. 3, No. 2, Des. 2020

Fidei: Jurnal Teologi Sistematika dan Praktika

Terakreditasi No: 85/M/KPT/2020 (Sinta 4)

e-ISSN: $2621-8135$

http://www.stt-tawangmangu.ac.id/e-journal/index.php/fidei

Vol. 3 No.2 (Des. 2020) hlm: 302-317

p-ISSN: $2621-8151$

DOI: $10.34081 /$ fidei.v3i2.174

Resensi Buku

\title{
The Early History of God: Yahweh and the Other Deities in Ancient Israel
}

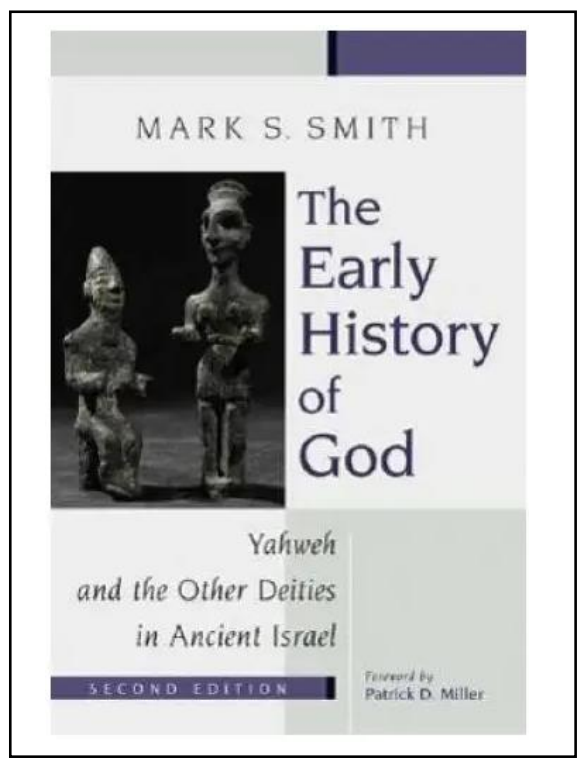

\section{Pendahuluan}

$\begin{array}{ll}\text { Judul Buku } & \text { : The Early History of God: } \\ & \text { Yahweh and the Other Deities } \\ & \text { in Ancient Israel }\end{array}$
barat seperti Frank Moore Cross, Michael D. Morgan dan Brevard S. Child. Akan tetapi, Smith lebih dikenal dengan model interpretasi Israel sebagai satu entitas dengan bangsa sekitarnya - dalam hal ini Kanaan. Pendekatan ini menghasilkan metodologi penting untuk melihat Israel dengan cara berbeda - yaitu Israel sebagai

${ }^{1}$ Mark S. Smith, The Early History of God: Yahweh and the Other Deities in Ancient Israel, ed. Patrick D. Miller, 2nd ed. (Grand Rapids: Eerdmans; Dearborn, Mich.: Dove, 2002), $1-243$.

Copyright@2020; Fidei: Jurnal Teologi Sistematika dan Praktika, e-ISSN: 2621-8135, p-ISSN: 2621-8151|302 
bangsa yang identik dengan bangsa-bangsa Kanaan - berlawanan dengan pemahaman yang selama ini melihat kedua bangsa sebagai vis-a-vis berdasarkan informasi Kitab Ibrani.

Buku ini berupaya menggambarkan upaya memahami Israel tidak dapat diperoleh melalui sejarah semata. Berbicara mengenai Israel sebagai umat dengan beberapa mishpat, kemudian berlanjut menjadi sebuah bangsa dalam koridor monarki, sampai mereka masuk dan kembali dari pembuangan; termasuk di dalamnya sistem agama mereka, hanya dapat dilakukan melalui memori. Memori yang dimaksud Smith dalam hal ini adalah melalui proses convergence dan differentiation. Pada masa awal Israel, bangsa ini tidak berbeda dengan bangsa-bangsa sekitarnya; termasuk di dalamnya sistem keagaman yang mereka anut. El, Baal, Anat dan Asherah menjadi allah utama Israel. El menjadi sesembahan utama Israel bersamaan dengan Yahweh. Baal menjadi sesembahan Daud ketika ia berseru Baal Perazim (allah memberikan terobosan) dalam 2 Samuel 5:20 dan 1 Tawarik 14:11 (hal.74-76).

Dengan ini kita melihat Smith justru menekankan natur Israel sesungguhnya berasal dari Kanaan. Budaya Israel secara alami adalah budaya Kanaan; budaya yang tidak dapat dipisahkan sejak jaman besi 1 (xxi); termasuk di dalamnya kultur beragama mereka - dalam hal ini termasuk allah Yahweh. Smith menentang pemahaman W.F. Albright yang melihat Yahweh berbeda dengan ilah Kanaan, dan oleh karena itu terdapat kontradiski di antara mereka. Bagi Smith, Yahweh, Ba'al, Aserah merupakan bagian dari budaya dan warisan Kanaan kepada Israel. (xxiii). Konsep biblikal mengenai allah Yahweh muncul secara 'berangsur-angsur' dalam suatu proses yang disebut Smith convergence and differentiation. Convergence merupakan perpaduan karakteristik para dewa, bahkan para dewa itu sendiri ke dalam penggambaran Yahweh. Proses ini jelas terlihat di era Hakim-Hakim dan periode monarki ketika El dan Yahweh mulai diidendifikasi; sekaligus Aserah dilihat sebagai satu kesatuan dengan Yahweh dan simbolnya menjadi bagian dari kultus Yahweh.

Sedangkan differentiation, menekankan pada penolakan kultus lama Israel karena dianggap sebagai budaya Kanaan. Tradisi-tradisi yang berhubungan dengan Ba'al, Aserah, penyembahan benda-benda langit, dan Bamot dianggap (ditetapkan) sebagai non Yahwistik. Dengan pemahaman differentiation inilah, maka, baik pihak kerajaan maupun nabi-nabi profetik mulai mengembangkan ideologi monolatri yang kemudian bermuara kepada monoteisme.

Studi yang dikembangkan Smith dalam buku ini memberikan warna baru dalam memahami, atau bisa dikatakan memberikan tantangan berbeda terhadap studi-studi tentang Yahwisme dan agama Israel yang sudah ada sebelumnya; terutama studi-studi yang membedakan dengan tajam antara sistem agama Kanaan dengan agama Israel seperti yang dilansir oleh Jeffrey Tigay ketika membahas onomastik Israel, atau karya William F. Albright yang yang melihat vis-à-vis antara sistem agama Kanaan dengan Israel, yang pada akhirnya ketika kedua budaya ini bersentuhan maka label 
"sinkretisme; bahkan sesat" muncul dengan beragam tendensi. Bagi Smith sejarah dan memori harus dibedakan. Tulisan-tulisan yang muncul di Israel harus dimengerti sebagai pekerjaan dengan memori, membentuk kembali cerita dengan harapan membentuk ingatan resmi akan kultur mereka.

\section{Tinjauan Isi Buku}

Pada bab pertama, Smith menelaah para ilah yang beroperasi di Israel pada era para Hakim. Budaya Israel dan Kanaan yang berasal dari matrix yang sama pada akhirnya memunculkan semacam kelanjutan keragaman hubungan antara ke dua budaya tersebut; seperti bahasa, material kultur, penggunaan nama, dan sistem kepercayaan. Berbagi (sharing) kultur antara kedua budaya lebih jelas terlihat dalam istilah-istilah seperti: zebah, selamin, neder, minhah, kalil dan istilah olah yang biasa dipakai di Israel; ternyata memiliki padanan makna identik dengan kultur persembahan korban di Kanaan.

Nama-nama biblikal yang memiliki latar belakang Kanaan bahkan dipakai dalam identitas pribadi yang dikultuskan, seperti: kohen, netuhim, netinim, serta istilah qades; semua ini merupakan istilah-istilah umum yang dipakai di kalangan Israel. Namun demikian, Smith juga mencatat ada beberapa gambaran Israel yang tidak bisa dihubungkan dengan kultur Kanaan - termasuk di dalamnya gambaran Yahweh di bait allah selatan yang termaktup dalam teologi Sinai ( Ul. 33:2; Hak.5:5), istilah Paran ( Ul. 33:2, Hab 3:3), Edom (Hak.5:4), dan Teiman (Hab3:3); juga termasuk di dalamnya inskripsi yang ditemukan di Kuntillet Ajrud (Amos 1:12; Yeh. 25:13), serta tradisi keluaran dari Mesir yang tercatat dalam Keluaran 15:4. Memperhatikan argumentasi ini, Smith terlihat memberikan penegasan bahwa latar belakang Israel secara umum adalah budaya Kanaan. Israel menerima/ mendapat warisan budaya ini sejak era akhir jaman perunggu yang dipercaya merupakan kelanjutan dari budaya Kanaan yang terbentang dari wilayah pantai barat dan terus berkembang pada jaman besi 1 ; termasuk di dalamnya kultur religiusnya.

Israel mungkin saja mempersepsikan diri mereka sebagai kelompok suku yang berbeda dengan orang Kanaan (narasi teks-teks pasca-pembuangan). Terpisah dalam bidang kepercayaan, terpisah karena asal usul (dipercaya mereka datang dari Mesir), dan terpisah secara geografis; di mana Israel berdiam di daerah pegunungan, sedangkan orang Kanaan berdiam di wilayah lembah dan dataran rendah Palestina. Namun, tidak bisa dipungkiri bahwa kedua bangsa banyak berbagi budaya dalam hampir segala aspek kehidupan. Kultur dan sistem kepercayaan mereka merupakan kelanjutan era akhir jaman perunggu; seperti kepercayaan terhadap El, Baal dan Aserah. Sehinggaa disimpulkan pada era jaman besi 1, Israel secara umum memiliki karakter Kanaan dalam konteks kultu, sosial dan sistem keagamaannya.

Dalam konteks allah Israel, Smith menetapkan asal muasal allah Israel adalah El. Rekonstruksi ini berdasarkan dua alasan, pertama, nama Israel tidak mengandung ide 
Yahwistik, melainkan El. Fakta ini menunjukkan El merupakan kepala panteon dari sistem keilahian Israel. Kedua, Kejadian 49:24-25 mempresentasikan serial mengenai El yang terpisah dari penyebutan Yahweh; khususnya ayat 18. Demikian pula Ulangan 32:8-9, menempatkan Yahweh sebagai yang tidak memegang peran dalam peranan yang dimainkan oleh anak-anak El, yang disebut elyon. Namun demikina, El dan Yahweh ditenggarai berjalan beriringan di Israel. Faktor-faktor yang mengindikasi El dan Yahweh berjalan beriringan pada awal-awal kerajaan adalah tidak ditemukannya polemik antara El dan Yahweh dalam kitab Ibrani. Nampaknya pada awal-awal kerajaan, tradisi Israel mengidentifikasi El dengan Yahweh atau keduanya identik. Bahkan tradisi para imam yang tergambar dalam Keluaran 6:2-3, mengidentifikasi El Shaday dengan Yahweh, yang dalam bagian ini Yahweh muncul di hadapan Musa dan berkata: akulah Yahweh, aku muncul dihadapan Abraham, Isak, dan Yakub sebagai El Shaday, tapi dengan namaku Yahweh aku belum menyatakan diri. Narasi ini merefleksikan Yahweh yang tidak dikenal oleh para Patriak, melainkan mereka menyembah Allah Kanaan El. Selanjutnya Smith memberikan argumentasi menarik perihal El dan Yahweh dalam hubungannya dengan tempat-tempat kudus seperti Sikhem dan Yerusalem - lokasi di mana El dan Yahweh dikenal dengan baik. Bagi Smith, Yahweh sepertinya mengalami semacam proses asimilasi di Sikhem dari allah lokal yang ada saat itu yang disebut el berit (Hak. 9:46; 8:33). Allah Sikhem el berit (allah perjanjian) yang kemudian menjadi el elohe Yisrael, Allah Israel, diasumsikan sebagai Yahweh. Bagi Smith, hal tersebut di atas dapat terjadi ketika kultus Sikhem menjadi Yahwistik; sekaligus tetap melanjutkan tradisi El yang ada. Itulah sebabnya Yahweh tetap mendapat julukan el berit. Penolakan dan fusi terhadap dan antara allah Kanaan deng Yahweh inilah yang dsebut Diveregence atau pembedaan, yang menurut Smith terjadi sekitar era para Hakim. Yahweh dinyatakan memainkan peran hegemoni atas ilah lainnya dengan tetap memberikan ruang tolereansi bagi allah lain seperti Aserah memainkan peran dan fungsinya di Israel.

Dalam bab ke dua pembahasan lebih diarahkan pada figur Baal dan Yahweh serta hubungan keduanya. Smith melihat nama-nama pribadi yang memiliki teoporik elemen Baal, seperti Jerubbaal, Ishbaal, dan Meribaal, memberikan indikasi bahwa masyarakat Israel; termasuk lingkungan kerajaan memandang penyembahan kepada Baal lazim dan sah dilakukan. Akan tetapi, berdasarkan inskripsi Samaria Ostraca, Smith menemukan penggunaan teoporik Baal ternyata hanya terdapat di Israel dan tidak di Yehuda. Data ini menimbulkan spekulasi bahwa penyembahan Baal ada kemungkinan telah mulai dan menyebar - terutama di wilayah Utara Israel sejak era Hakim-Hakim sampai dengan kejatuhan Samaria tahun 722 SM, yang dibawa oleh Jesebel. Sumber-sumber biblikal maupun extra-biblikal sepakat menempatkan abad ke 9 SM sebagai periode di mana informasi pertama tentang Baal di Israel hadir. Di antaranya ditemukan catatan biblikal yang memberikan gambaran hadirnya Baal Fenisia di Israel yang dibawa/ dibangun oleh Jesebel dan Ahab (1 Raja-Raja 16:31). 
Apabila merunut catatan biblika, maka Baal yang dibangun Jesebel adalah allah yang menguasai hujan dan badai. Namun persoalan timbul ketika banyak pendapat ahli biblika yang mengidentikkan ilah yang disembah Jesebel ternyata adalah Baal Melqart; dewa yang diidentifikasi tidak menguasai hujan, petir dan guruh. Untuk itu, Smith berusaha membuat argumentasi sekaligus membuktikan bahwa Baal Merqat bukanlah Baal yang disembah Jesebel. Sumber-sumber extrabiblikal; seperti inskripsi Biblos (KAI 4:3), Karatepe (KAI 26 A III 18), Kition (RES 1519b), mengindikasikan ada tiga macam Baal yang beroperasi di Tirus: Baal Shamem, Baal Malaga, dan Baal Sapon. Baal Shamem dipercaya sebagai allah badai yang diasosiasikan dengan langit dan surga; sekaligus disetarakan dengan Zeus. Berdasarkan argumentasi ini, maka Baal Shamem (dan bukan Melqart yang disembah Jesebel) yang menjadi ancaman bagi Israel.

Untuk menguatkan asumsinya, Smith mempergunakan Mazmur 20 sebagai landasan pijak untuk memberikan refleksi dari gambaran asli Israel mengenai Baal melalui referensi terhadap Baal Shamem, EL Betel dan gunung Sapan sebagai deskripsi original Kanaan dan seting kerajaan Utara. Dengan hadirnya referensi terhadap Baal Shamem, maka dapat diperkirakan dampak yang timbul di kerajaan Utara saat itu Baal Shamem yang didukung oleh Jesebel dan Ahab memainkan peran siknifikan dalam konteks sosial Israel; khususnya kerajaan utara. Namun demikian, Smith tetap yakin walau kultus Baal mendapat sponsor kuat kerajaan, masih ada kekuatan dari kultus Yahweh yang beroperasi berdampingan dengan kultus Baal berdasarkan catatan 1 Raja-Raja 18:22, di mana tidak ada pelarangan dari pihak kerajaan terhadap kultus Baal yang ada saat itu. Berdasaran teks 1 Raja-Raja 16:30-33 dan 21:25-26, Ahab sendiri tidak menunjukkan "berhianat" dari kultus Yahweh. Bahkan anak-anaknya, Ahaziah (1 Raja-Raja 22:40) dan Yoram (2 Raja-Raja 1:17; 8:5) menggunakan nama Yahwistik. Bahkan setelah ia berkonflik dengan Elisa, Ahab dikabarkan berkonsultasi dengan nabi Yahweh (1 Raja-Raja 20:13-15, 22, 28). Penyembahan terhadap Baal terus berlanjut di tengah-tengah berbagai upaya untuk meruntuhkannya, seperti: Yoram (anak Ahab) yang melakukan reformasi (2 Raj. 3:2), Atalia dan Matan; nabi-nabi Baal yang dibunuh (2 Raj.11:18). Tetap saja kita melihat penyembahan terhadap Baal berkelanjutan. Beberapa teks biblika menunjukkan Baal tetap diterima dan diteruskan bahkan sampai pada akhir era Yehuda.

Smith memasukkan the bull icnography yang diusung Yerobeam 1 di Dan dan Betel (1 Raj. 12:28-31) sebagai mendapat pengaruh dari Baal kerajaan Utara. Ide bull ini bisa juga dikaitkan dengan figur El yang dalam Kej.49:24 disebut dengan abir ya aqob. Gambaran Yahweh sebagai "tanduk kerbau liar" dalam Bilangan 24:8 nampaknya mengikuti latar belakang ini. Jadi, polemik terhadap ide "lembu tuangan" dalam Hosea 8:5 dan 10:5 mungkin sebagai reaksi "berlebihan" dari Hosea yang melihat simbol Yahweh diasosiasikan dengan figur Baal. Pada akhirnya kita melihat semua motif yang diasosiasikan dengan Baal dalam literatur Kanaan secara luas termanifestasi dalam sistem agama Israel. Para Rabbi yang menulis ulang kisah Israel 
sepulangnya dari pembuangan dan literatur-literatur Kristen, meneruskan semua motif ini dan tetap dianggap penting sampai pada era terkemudian.

Bab tiga memuat materi kehadiranYahweh dengan Aserah dan korelasi ke dua ilah ini di Israel. Teks-teks sejarah seperti Hakim-Hakim 3:7; 6:25-30, Keluaran 34:13, Ulangan 7:5, 12:3, dan teks-teks profetik seperti Yesaya 17:8, Yeremia 17:2 dan Mikha 5:13, memberikan indikasi penyembahan terhadap kultus dan simbol Aserah telah dilakukan jauh sebelum era Hakim-Hakim dan terus bertahan sebelum kejatuhan kerajaan selatan (2 Raj.23:4,6,7). Mengutip Saul M. Olyan, Smith melihat Aserah diterima dengan baik di Israel dan di Yehuda yang menjadikan Aserah dan semua simbolnya legal di Israel. Lebih jauh Smith melihat tidak pernah ada indikasi penyembahan terhadap Aserah (simbol) dibatasi pada kelompok atau strata sosial tertentu di Israel. Kritik terhadap Aserah hanya dilakukan oleh satu kelompok kecil di Israel yang disebut kaum Deuteronomis, dan ini hanya dilakukan pada pada sekitar abad ke 8 SM. Israel mayoritas menerima figur Aserah sebagai ilah sesembahan atau jika mereka tidak menyembahnya, tidak pula menentang. Hal ini diperkuat catatan Yehu dan Hosea yang tidak menunjukkan resistensi terhadap ilah ini. Walaupun dalam narasi umum, Aserah adalah sesuatu yang "dibuat" (1 Raj. 14:15), "dibangun" (1 Raj.14:23), "set up" (2 Raj.17:10), dan "planted” (U1.16:21). Dengan kata lain ia buatan manusia. Konsekuensinya banyak narasi biblikal membuat prasangka negatif bahkan memberikan label ilah palsu kepada Aserah; ilah yang menjadi fenomena di Israel (hal.88).

Smith mengajukan dua pertanyaan penting mengenai fungsi dan peran Aserah dalam sistem keagamaan Israel: pertama, apakah figur ini adalah seorang dewi/ ilah dan menjadi pasangan Yahweh di Israel kuno? Ataukah data yang menghubungkan Aserah dengan kultus Yahweh tidak memiliki siginifikansi sama sekali? Smith mencatat para ahli seperti Fohrer, Ahlstorm, Dever, Freedman, Olyan dan Lemaire, cenderung mengikuti poin pertama, sedangkan kaum minoritas yang mengikuti poin kedua adalah Lang, Miller, Tigay, dan Winter. Namun demikian, terlihat banyak bukti dari penemuan beberapa inskripsi dan teks biblika seperti Kej. 49:25 yang memberikan sinyalemen Aserah merupakan pasangan Yahweh. Aserah digambarkan figur ilah yang berfungsi sebagai allah bersama-sama dengan Yahweh dengan mengambil peran ilah kesuburan dan pelindung. Analisis ini mendapat pembenaran dalam teks-teks di luar Deuteronomis yang tidak pernah mempermasalahkan eksistensi Aserah di Israel; salah satu bukti nyata adalah Elia tidak mengkutuk para nabi Aserah yang hadir bersama nabi Baal di gunung Karmel.

Namun demikian, Smith terlihat menunjukkan keraguan terhadap bukti keberadaan Aserah sebagai pasangan Yahweh. Walaupun ada teks-teks biblikal (1 Raj.18:19 dan Kej. 49:25) yang menyatakan ia sebagai pasangan Yahweh, namun tetap terbuka untuk perdebatan. Kesulitan lain untuk menetapkan Aserah sebagai allah di Israel; selain tidak adanya sumber dari bukti biblikal, adalah sumber dari teks Fenisia 
yang juga tidak memiliki informasi jelas tentang Aserah. Bagi Smith Aserah bukan ilah yang disembah di Fenisia selama era Jaman Besi 1. Apabila budaya Israel merupakan kelanjutan dari budaya Fenisia, maka Aserah bisa dinyatakan tidak pernah hadir di Israel; tidak termasuk melihat kepada tidak adanya nama-nama persona yang menggunakan teoporik nama Aserah. Fakta ini menunjukkan tidak adanya elemen kultus yang kuat dari dewi ini di Israel. Dan pada akhirnya bisa dipastikan bukti kehadiran ilah ini di Yehuda sangat diragukan. Untuk itu, pandangan para ahli minoritas seperti Lang, patut mendapat perhatian.

Jika simbol yang merepresentasi Aserah secara historis dipertanyakan, maka pertanyaan yang muncul adalah mengapa tradisi Deuteronomis begitu menentang simbol ini? Atau jika simbol-simbol Aserah tidak lagi merepresentasi sang ilah, mengapa masih ditolak? Smith tidak memberikan jawaban an sich dari pertanyaanpertanyaan tersebut. Apabila figur dan simbol Aserah seperti: menyapih, maternal, hikmat, dan pohon kehidupan terserap dalam figur dan kultus Yahweh, maka pertanyaan yang muncul kemudian adalah: seperti apakah bahasa jender Yahweh? J.W. Miller, yang mempergunakan teks Ulangan 32:18; Bilangan 11:12; Mazmur 22:9-10, dan Yesaya 46:3; 66:9, 13, yakin bahasa yang dipergunakan bergender laki-laki, dan penggunaan gambaran perempuan dalam bahasa Yahweh lebih bersifat metaforis.

Argumentasi Miller nampaknya ditentang Smith. Bagi Smith, Yahweh dideskripsikkan baik sebagai laki-laki maupun perempuan, sama seperti ilah-ilah dalam dunia Timur Dekat Kuno lainnya. Yahweh bisa saja menerima metaphor perempuan tanpa harus dimengerti sang ilah menjadi laki-laki sekaligus perempuan gendernya. Yahweh bisa saja memiliki gambaran perempuan tanpa wajib menerima pengaruh dari ilah-ilah bergender perempuan lainnya. Dengan ini, pengaruh dari Aserah terhadap kultus Yahweh dan gambaran Yahweh itu sendiri pada dasarnya dapat dipilah dan dikenal. Gambaran Yahweh sebagai Allah dengan figur laki-laki tanpa pendamping, mendominasi diskursus religius di masyarakat Israel Kuno, atau paling tidak dalam hubungannya dengan tataran realitas keberagamaan dalam tingkat-tingkat tertentu. Bagi Israel, Yahweh dipandang sebagai Allah, walaupun ia juga dipandang sebagai suatu realitas yang didiami (embodying) jejak-jejak atau nilai-nilai yang diekspresikan oleh beberapa metaphor gender tertentu.

Bahasa feminin yang dikenakan pada Yahweh bisa berasal dari fleksibiltas bahasa keilahian itu sendiri. Dalam hal ini apabila gambarannya dihubungkan dengan Aserah, maka akan berfungsi sebagai latar dari bahasa keilahian itu sendiri, seperti dalam catatan Amsal 3:13-18, sang ilah (Aserah), atau simbolnya yang terlihat memberikan dampak seperti terserapnya El dan Yahweh. Jadi, jika dampak gambaran Aserah terhadap Yahweh dapat dideteksi, maka, ada kemungkinan efek dari asimilasi ini lebih besar dari yang pernah diduga sebelumnya. Dengan ini, kita dapat mengasumsikan peran Aserah yang besar di Israel kuno. 
Pada bab empat, Smith melihat Yahweh dalam hubungannya dengan matahari atau dewa matahari. Catatan mengenai bahasa surya dalam teks biblikal terbilang minim. Contoh klasik yang bisa dipergunakan adalah Mazmur 84:12 "ke semes umagen yhwh" for a sun and shield is Yahweh. Walaupun bahasa dalam Mazmur ini bersifat figuratif, namun dapat dipergunakan untuk menjelaskan hubungan Yahweh dengan penyembahan matahari, apalagi seting dalam Mazmur ini adalah pengharapan para peziarah yang mengharapkan dapat berbicara dan melihat Yahweh di Zion. Motif "melihat tuhan" di mana Yahweh berdiam di Yerusalem dan dari sana "cahaya" Yahweh memancar, menjadi pertanda kehadiran sekaligus berkat ilahi; juga menjadi petunjuk Yahweh yang dihubungkan dengan matahari, atau Yahweh adalah dewa matahari itu sendiri.

Selain itu, ide "bangkit" yang biasa dikenakan kepada Yahweh dalam Ulangan 33:2; Yesaya 60:1; Hosea 6:3, serta inskripsi dari Kuntilled Ajrud, menunjuk kepada ide surya atau cakrawala Yahwisme yang mana ia biasa dijuluki sebagai sang Surya, terang, atau yang bangkit. Sehingga kita dapat berasumsi penyembahan terhadap Yahweh dalam format penyembahan surya pasti terjadi di Yerusalem; bahkan terus berlangung sampai pada akhir masa monarki Yehuda.

Apakah ada peran monarki Israel dalam penyembahan Yahweh matahari ini? Menurut Smith, pada era jaman besi 1, semua raja-raja Israel; utamanya Yahweh, sering dimetaforakan sebagai surya, terkadang dikombinasikan dengan gambaran hujan (penguasaan terhadap hujan). Misalnya teks Hosea 6:3, yang membandingkan Yahweh dengan matahari dan hujan. Bahkan 2 Smuel 23:3 membandingkan sang raja dengan matahari saat terbenam dan hujan saat ia menjadi penyebab tumbuhnya tumbuhan. Bahkan Smith melihat penggunaan gambaran surya terhadap Yahweh berlanjut pada stempel kerajaan yang pernah ditemukan. Untuk itu Smith menyimpulkan penggunaan kiasan bahasa surya atau perbintangan untuk Yahweh mungkin saja berkembang dengan baik karena pengaruh monarki saat itu (hal. 119).

Pada akhirnya Smith melihat perkembangan kiasan surya/perbintangan terhadap Yahweh berkembang dalam dua tahap. Pertama, ide penyembahan matahari ini merupakan bagian integral dari kultur Kanaan dan dunia timur dekat kuno pada umumnya ketika Yahweh dapat dianggap dipandang sebagai allah surya atau allah badai, atau ke duanya. Kedua, dibawah pengaruh monarki, matahari menjadi salah satu komponen simbolik yang menjadi dimensi ekspresi hal keilahian dan kemanusiaan yang dimiliki oleh pamteon ilahi serupa, seperti yang lazim terjadi di Ugarit, Babel, dan Asyur. Penggunaan ini nampaknya sangat umum dan spesial di Yehuda; sekaligus minim bukti hal ini hadir di Israel.

Khususnya hubungan Yahweh dengan dewa matahari dan bulan, terlihat penyembahan terhadap matahari, bulan, bintang-bintang dan balatentara langit, seringkali dihubungkan dengan penyembahan kepada Yahweh itu sendiri. Artinya figur dan fungsi Yahweh sering bertukar tempat dan bahkan identik dengan ilah-ilah tersebut. 
Hubungan antara Yahweh dan matahari yang kemudian terbingkai dalam ide "Yehovah Sebaot" dan "Yahweh sang matahari" inilah yang mendapat tekanan dalam pembahasan bab ini untuk membuktikan bahwa penyembahan terhadap matahari, bulan, bintang dan balatentara langit yang pernah dilakukan umat Israel, memiliki substansi identik dengan/ ketika mereka menyembah Yahweh.

Menurut Smith, Ada beberapa bagian dari kepenulisan nabi-nabi terakhir yang membahas penyembahan kepada matahari dihubungkan dengan Yahweh. Yesaya 2:7, berbicara mengenai kutukan sang nabi terhadap penyembahan matahari; termasuk di dalamnya kutukan terhadap kuda-kuda dan kereta yang diasumsikan memuat segala kekayaan yang dipersembahkan kepada dewa matahari. Ide ini diperkuat melalui catatan Yesaya 19:18, yang memberikan gambaran hadirnya kultus Yahweh-Matahari yang mana arti ir-heres dalam ayat itu dapat diterjemahkan sebagai "kota matahari." Apabila dhubungkan dengan salah satu gelar Yahweh; "Yahweh Sebaot" yang artinya balatentara Allah/ langit, maka ide balatentara Allah yang datang dari angkasa cocok dengan kota matahari sebagai suatu tempat yang telah mengalami restorasi di mana Yahweh bertahta dan memerintah, atau dalam bahasa Perjanjian Baru kira-kira mirip dengan Langit Baru.

Salah satu teks dalam Yesaya yang ekplisit menghubungkan Yahweh dengan matahari adalah Yesaya 60.1-3. "Bangkitlah, menjadi teranglah, sebab terangmu sudah datang, dan kemuliaan Tuhan terbit atasmu. Sebab, sesungguhnya kegelapan menutupi bumi dan kekelaman menutupi bangsa-bangsa; tetapi terang Tuhan terbit atasmu, dan kemuliannya nyata atasmu. Bangsa-bangsa berduyun-duyun datang kepada terangmu dan raja-raja kepada cahaya yang terbit bagimu dan keadilannyalah yang membantu dia." Bahwa kemuliaan Yahweh digambarkan dalam cahaya matahari, jelas dalam bagian ini yang mendukung ide Yahweh-Matahari, karena kata kerja "menjadi teranglah" lebih menunjuk kepada sosok Yahweh sebagai figur yang menggantikan dewa Matahari. Sepertinya istilah zarah "bangkitlah" (seperti matahari), merupakan referensi kepada cahaya kebod yhwh "cahaya kemuliaan Yahweh" yang bersinar dari atas masuk ke dalam Bait Allah yang juga dapat menjadi pertanda terjadinya pergantian musim.

Dalam Yesaya 60. 19-20, muncul kalimat "bagimu matahari tidak lagi menjadi penerang di siang hari dan cahaya bulan tidak lagi memberi terang pada malam hari, tetapi Tuhan akan menjadi penerang abadi bagimu dan Allahmu akan menjadi keagunganmu. Bagimu akan ada matahari yang tidak pernah tenggelam dan bulan yang tidak surut, sebab Tuhan akan menjadi penerang abadi bagimu, dan hari-hari perkabunganmu akan berakhir." Dari struktur kalimat yang tertera dalam dua ayat di atas, nampaknya tercermin ide bahwa Yahweh menggantikan peran dewa matahari dan menjadi bentuk ibadah legal di Israel saat itu. Dengan ini kita melihat bahwa Yahweh dan dewa Matahari walaupun sering dibedakan, namun keduanya memiliki hubungan dekat dan bahkan identik satu dengan lainnya. Selain itu, nampaknya muncul nuansa 
eskatologis ketika Yahweh dihubungkan dengan suatu masa yang lebih bersinar di kemudian hari. Ide ini tentunya cocok dengan ekspektasi para pengikut Yesaya pascapembuangan yang ketika kembali dari pembuangan tidak lagi melihat ada harapan bait suci dan kerajaan Daud dibangun kembali. Kehilangan pengharapan ini mendapat jalan keluar melalui pengharapan eskatologi akan tempat yang lebih terang dari kegelapan yang mereka miliki saat itu. Untuk itu, dapatla diasumsikan bahwa penyembahan Yahweh yang dihubungkan dengan dewa matahari dalam kitab Yesaya (terutama Yesaya pasca-pembuangan), masih tetap berlangsung di era Yudaisme ketika Israel telah kembali dari pembuangan, sebab ide Yahweh-Matahari masih kuat melekat dalam ingatan kaum Judais saat itu.

Pada bab lima, Smith membahas catatan biblikal mengenai kultis di luar Yahweh yang pada akhirnya ditolak di kalangan Deuteronomis walaupun simbolnya diterima dalam kultus Yahweh sebelumnya. Tidak hanya Aserah saja yang ditolak, altar dan pilar-pilar pemberian korban yang berhubungan dengan Aserah juga dianggap kenajisan bagi Allah (Ul. 34:13; 16:22). Bahkan catatan Yeremia tidak saja menolak Aserah, altar dan pilar penyembahan, tetapi juga tidak mengijinkan bamot (Yer 17:2) yang sebelumnya oleh para leluhur Israel dipakai sebagai tempat dan sarana ibadah kepada Yahweh. Semua penolakan ini bisa kita rangkum dalam teks Mikha 5:10-15, di mana semua pertenungan, ahli nujum, patung tuangan, pilar persembahan korban dan Aserim harus dihilangkan dari hadapan Yahweh. Padahal beberapa dari praktik ini dimiliki kultus Yahweh yang dikemudian hari memang terindikasi aktif ketika masih legal dipergunakan; sekaligus mendapat kutukan dan tentangan. Bagi Smith, bamot merupakan objek legal di Israel dan Yehuda. Bahkan catatan Deuteronomistik pernah membuat pembenaran terhadap fungsi bamot, seperti yang terekam dalam Ulangan 12:1-14. Untuk menguatkan argument ini, Smith percaya monarki sendiri mendukung bamot (2 Raj. 23:8 dst) yang berfungsi baik di pedesaan maupun di kota-kota besar kerajaan, bahkan terus berfungsi sampai pada era Yosia.

Penolakan terhadap Aserah, ternyata berlanjut pada penolakan dan kutukan terhadap ritual persembahan korban manusia (anak) yang dimiliki Israel sebagai bagian dari budaya Kanaan yang terserap atau warisan Kanaan. Israel kuno meneruskan prakek ini berdampingan dengan praktik pada kultus Yahweh, dan menjadi "agama Yahwistik resmi." Bagi Smith, pelarangan terhadap praktik yang berhubungan dengan orang mati di Israel, terjadi pada sekitar abad ke 7 SM, dan ini karena berhubungan dengan Necromanci dan divinitation yang mungkin dianggap sebagai tandingan atau lawan dari nubuatan. Padahal, praktik yang berhubungan dengan orang mati maupun necromancy sudah berlangsung lama di Israel; bahkan dianggap telah mulai hadir sejak jaman besi 1; termasuk di dalamnya ritual perkabungan bagi orang mati, memberi makan orang mati dan memohon kepada orang mati sebagai sumber informasi ilahi serta pertolongan. Upacara-upacara ini berkembang dalam berbagai strata sosial di masyarakat Israel. 
Smith bahkan menduga upacara yang berhubungan dengan orang mati membentuk gambaran sentral dari kehidupan keluarga dalam keseluruhan sejarah Israel.

Menurut 2 Samuel 18:18, Absalom mendirikan tonggak pemakaman sebagai memori karena ia tidak memilik anak. 2 Tawarik 16:12, merekam Asa yang mencari pertolongan atas sakitnya terhadap orang yang sudah meninggal. Teks ini menceritakan Asa yang sakit dan tidak mencari Yahweh, melainkan mencari pertolongan kepada rope im (penyihir) atau repa aim (orang mati). Smith cenderung mengarahkan pembaca untuk percaya bahwa Asa mencari pertolongan kepada orang mati "repa aim", berdasarkan kata kerja drs yang selalu berhubungan dengan hal keilahian.

Dukungan terhadap praktik yang berhubungan dengan orang mati, menurut Smith, tidak hanya dilakukan oleh orang biasa dan royal dinasti saja, melainkan dilakukan juga oleh para nabi. Paling tidak beberapa nabi mentolerir tradisi penguburan ala kerajaan ini seperti yang terekam dalam teks Yehezkiel. 43:7-9. Bahkan para nabi awal dipercaya tidak menolak necromancy. Kisah tulang-tulang Elisa dalam 2 Raja-Raja 13:20-21, juga memperlihatkan kaum profetik di kerajaan Utara melihat kekuatan orang mati sebagai sesuatu yang harus diperhitungkan. Smith bahkan yakin necromancy dan doa kepada orang mati terus bertahan sampai pada era Yahudi; yang dibuktikan dengan teks dalam 2 Baruk 85:12b dan Pseudo Phillo 33:5.

Sedangkan persembahan korban anak dapat terlihat dalam banyak teks kitab Ibrani; misalanya Yeremia 19:5; 32:35; Maz. 106:34-38; 2 Raj. 17:31, dan lain sebagainya. Persembahan korban manusia (anak) nampaknya menjadi upacara legal di Israel; bahkan dilegalkan dalam nama Yahweh di Yehuda (Yeh. 20:25-26). Smith menggunakan Yesaya 30:27-33 untuk menggambarkan bahwa persembahan anak sebagai korban di Israel merupakan sesuatu yang harus dilakukan untuk mengantisipasi kedatangan Yahweh yang membawa kehancuran. Mengutip Phillo dari Byblos, Smith melihat ritual ini telah menjadi sangat umum bagi para pemimpin dan penguasa di masyarakat kuno yang sedang berada dalam keadaan genting dan kritis - ritual yang wajib dilakukan untuk mengantisipasi kerugian atau kehilangan yang lebih banyak dalam masa kesulitan yang terjadi; untuk itu mereka cenderung memberikan/ menyajikan anaknya yang paling tersayang sebagai korban penebusan kepada ilah-ilah yang sedang murka. Sang anak kemudian disembelih dan dipersembahkan kepda sang ilah. Dan jika memungkinkan, yang diberikan biasanya anak yang paling dijaga atau anak tunggal.

Merunut pada teks Biblikal Hebraica (apapun latar belakang yang ada), Smith melihat ritual persembahan anak sudah menjadi suatu bentuk ritual yang telah diterima/ atau minimal dapat diterima, dan mungkin terjadi sekitar paruh kedua monarki di Israel dan Yehuda. Sama seperti Bamot, persembahan korban anak rupanya dikenal juga di Moab (selain Israel), dan jika teks Yeremia 7:30-32 dan 32:35 merupakan indikasi dari praktik ini, maka, Smith yakin modus persembahan korban anak pastinya dilakukan di bamot. Namun demikian, agama bamot secara umum merupakan sistem keagamaan 
yang mengandung unsur Yahwistik; baik dalam nama maupun praktiknya, yang memberikan variasi lebih luas dari aktivitas kultik dan melampaui apa yang bisa diberikan para kritikus pada paruh kedua monarki. Praktik religius di bamot bisa dikatakan sebagai suatu bentuk praktik religius yang sangat konservatif yang tetap mempertahankan/ menjaga nilai-nilai religius warisan leluhur. Dan untuk ini, mungkin kita bisa menyimpulkan banyak dari bentuk praktik bamot ini yang dilakukan juga oleh orang-orang di kerajaan/ atau para pejabat kerajaan Yerusalem. Segala bentuk penentangan terhadap sistem kepercayaan ini, lebih disebabkan karena bangsa, keluarga, dan family di luar Israel, juga turut melakukan praktik ini. Sebab atas nama ilah apapun praktik keagamaan bamot ini diberikan, pada akhirnya praktik ini dianggp tidak layak berada di Israel pada era terkemudian.

Memasuki bab yang ke-enam, Smith membahas asal-muasal dan perkembangan monoteisme di Israel. Rekonstruksi sejarah keagamaan Israel menurut Smith harus dapat melihat pentingnya ilah lain selain Yahweh. Seperti yang sudah dibahas sebelumnya mengenai para ilah di Israel yang sangat terbatas apabila dibandingkan dengan yang ada di Ugarit, Mesopotamia, atau Mesir. Pada era Hakim-hakim, para ilah di Israel yang umum dikenal adalah Yahweh, El, Baal, Aserah. Masuk pada era monarki, kita menemukan Yahweh, Baal, Astarte, the Sun, Moon, dan Bintang-Bintang yang dikategorikan ilah-ilah legal Israel. Selain itu ada Aserah, Istar atau Anat. Ilahilah terakhir ini menurut Smith muncul pada periode akhir monarki di Yehuda.

Pada era di mana begitu bervariasinya ilah yang disembah di Israel, maka, ide sinkretistik bukan merupakan pemikiran tepat untuk menggambarkan variasi keagamaan Israel. Smith berargumen, Yahwisme saja bisa bervariasi dari satu tempat ke tempat lain, sehingga indikasi hadirnya poli-Yahwisme bukan wacana. Asimilasi simbol El dan Aserah ke dalam kultus Yahweh telah menciptakan Yahwisme dengan kultur Kanaan. Smith bahkan berasumsi, Israel mungkin mengenal atau mempraktikkan ditheism dalam level tertentu sebagai bentuk penyembahan mereka kepada Yahweh (Kej. 49:25). Walaupun ditheisme Yahwistik ini ditentang oleh monoteistik Yahweh di era terkemudian tetap tidak memberikan indikasi bahwa non monoteistik Yahwisme merupakan "sinkretisme Kanaan", dinodai oleh praktik-praktik Kanaan dan karenanya bersifat non-Yahwistik.

Di bawah pengaruh kerajaan, agama memadukan ekspresi kuat negara bersamaan dengan ideologi agama. Kredibilitas dinasti ikut diperkuat ketika allah nasional naik prestisenya. Dan pada era monarki inilah - terutama di era Daud, tercipta hubungan khusus antara Yahweh dengan dinasti Daud yang kemudian membentuk (terbentuk) suatu ikatan perjanjian yang disebut berit olam "eternal covenant" (2 Sam. 23:5). Terbentuknya ikatan perjanjian ini yang termaktup di dalamnya seluruh tanah dan umat yang juga secara otomatis memberikan jaminan terhadap kesejahteraan seluruh negeri, keadilan yang terpenuhi dan kesuburan (Maz. 2; 72;89; 110), sebagai 
gantinya, raja membuat kultus nasional kepada Yahweh. Dengan hegemoni nasional terhadap Yahweh telah tercipta di Israel kuno.

Inovasi dari sentralisasi penyembahan nasional berjalan sekaligus menjadi bagian dari suatu proses menuju monoteistik Yahwisme, di mana hanya satu allah saja yang diakui dan menolak ilah lainnya. Hal ini hanya dapat tercipta jika terjadi semacam unifikasi dari seluruh aspek kehidupan rakyat - baik politik maupun religius yang kemudian menolong mendapatkan sentralisasi secara politis dan kultis dengan melakukan konsentrasi dan pameran kekuatan diseluruh ibu kota erta relasi dengan iklah nasional yang ada di kota itu. Perkembangan ini tentunya sejalan seiring dengan perkembangan kota/ kerajaan - yang dalam hal ini adalah kerajaan Daud itu sendiri. Kebijakan politik yang dibangun Daud dengan melakukan unifikasi penyembahan terhadap Yahweh, memiliki efek penyatuan cara di mana ia dipahami atau dimengerti oleh pengikutnya; sekaligus proses ini mengeliminasi semua tradisi dan manifestasi lokal yang ada. Namun demikian, Smith tetap memandang peran monarki tetap tidak terlepas dari aspek inovatif sekaligus konservati, sebagai bentuk reaksi terhadap kebutuhan berkembangnya suatu Negara.

Faktor lain yang memberikan peran besar terhadap sentralisasi dalam periode monarki - yang sama besarnya memberikan pengaruh pada perkembangan monolatri adalah peran tulisan dalam masyarakat Israel. Mengutip dari J. Goody, Smith percaya bahwa lahirnya bentuk tulisan telah menolong untuk mempercepat proses monolatri. Lahirnya tulisan telah memberikan kebiasaan-kebiasaan kepada hukum lisan dalam bentuk aplikasi yang lebih umum sekaligus lebih berotoritatif dalam masyarakat. Sebagai hasilnya, norma-norma sosial dalam forma tulisan menjadi semakin otoritatif terhadap audiens yang lebih luas. Smith memasukkan beberapa contoh peranan tulisan dalam perkembangan tradisi hukum di periode monarki yang terekam dalam beberapa teks seperti: Yer. 8:7-8; 2 Raj. 22:3; 23:24; Hos. 8:12; 1 Taw. 17:7-9; 24:6, dan muncul secara jelas dalam teks-teks pasca-pembuangan seperti dalam Ezra 7:6, 11; Neh. 8:1, serta banyak terdapat dalam teks sejarah narasi yang berakhir dengan kalimat: demikianlah riwayat.

Ketika menjadi patron dari ilah nasional, Yahweh menurut Smith terlihat diberikan peran besar; bahkan dukungan terhadap konflik yang berskala internasional untuk meluaskan pengaruhnya oleh para pendukungnya. Ide "Yahweh only party" yang mulai berkembang di abad ke 9 SM ini mulai mempromosikan diri dalam bentuk iman monolatrinya. Kasus Elia dan Elisa merupakan contoh gamblang ketika Naaman pada akhirnya mengakui "tidak ada tuhan di kolong langit ini selain yang di Israel (2 Raj. 5:1). Tulisan puitik seperti Maz. 47:2; 8:1; 24:1; 48:2; 95:4, dan Yes. 6:3, yang terlibat dalam serangkaian konflik politik dan religius dengan bangsa lain pada era sebelum pembuangan, dipercaya telah memberikan konteks politik bagi ekspresi dari kekuasaan pemerintahan Yahweh yang semula hanya atas Israel, berkembang atas musuhmusuhnya. Yahweh bukan hanya allah Israel, melainkan menjadi allah seluruh bangsa. 
Ekspresi ini menurut Smith, terus berlanjut sampai pada era para nabi abad ke 8 dan mengalami masa jayanya ketika mulai muncul ide monoteisme Israel di pembuangan.

Namun demikian, Smith juga melihat peranan monarki yang begitu besar dalam memberikan penguatan gambaran-gambaran religious dari ilah-ilah lain ke dalam kultus Yahweh. Hadirnya figur Aserah, bahasa dengan simbol dewa bintang, necromancy, atau memberi makan orang mati, nampaknya memberikan sinyal monarki masih menerima praktik-praktik ini. Bagi Smith, monarki masih tetap menjaga dan menyimpan tradisi-tradisi ini dalam suatu bentuk toleransi tertentu. Jadi, isu yang seharusnya diangkat bukan mengapa monarki masih menerima praktik-praktik ini, melainkan mengapa praktik ini ditentang oleh beberapa nabi.

Menurut Mark S. Smith, perubahan-perubahan dalam kaitannya dengan differentiation mulai terjadi dari beberapa gambaran liturgi kepada Yahweh, seperti penyembahan terhadap kultus Baal dan beberapa praktik yang berhubungan dengan orang mati yang mulai memberikan sinyal munculnya pemisahan - operasional berbeda dari periode terdahulu yang saling melekat. Polemik Hosea terhadap penyembahan Baal merefleksikan hadirnya differentiation yang semakin kuat dan meluas di Israel dari yang sebelumnya masih diakui dan ditoleransi, kini ditentang. Demikian pula bahasabahasa satir Yeremia terhadap dewa-dewa tuangan (Yer. 10), telah memainkan peran hadirnya ide "allah sesungguhnya", atau "ia yang hidup dan yang kekal" yang mengarah kepada Yahweh sebagai satu-satunya allah Israel.

Bentuk tulisan yang semula sudah memainkan peran penting dalam sentralisasi menuju monolatri, pada era ini menjadi semakin kuat memainkan perannya bagi tradisi hukum dan nubuatan. Material-material hukum telah dibentuk dan dibangun dalam tulisan-tulisan otoritatif. Dua bentuk 10 hukum Taurat dan model kelanjutannya dalam Ul. 12-26, mengindikasikan peran tulisan yang semakin kuat dalam masyarakat, yang kemudian menganggap tulisan sebagai produk Yahweh, sang penulis agung (Ul. 9:10; 10:2,2). Pada akhirnya tulisan menjadi moda utama dalam mempertahankan lingkaran propetik; termasuk di dalamnya cerita Elia, Elisha, dan murid-muridnya, yang mana tren ini terus berlanjut sampai kepada nabi-nabi abad ke 8 dan 6 SM (Yes. 8:19-20). Tulisan-tulisan hikmat menurut Smith sangat bergantung kepada hadirnya bentuk tulisan yang memainkan peran besar dan efektif dalam menyimpan dan mendistribusikan teks-teks hukum dalam masyarakat Israel.

Bagi Smith, monoteisme bukan produk awal Israel. Monoteisme lahir berdasarkan proses convergence - proses di mana terjadi peleburan atau berfusinya beberapa ilah sesembahan Israel seperti El dan Baal ke dalam figur Yahweh. Convergence ini merupakan produk awal gerakan "Yahweh semata Israel yang kemudian akan dilanjutkan dengan proses monolatri dan monoteisme. Monolatri sangat mengandalkan monarki sebagai titik tolak perkembangannya. Sedangkan konsep differentiation membentuk agama "Yahweh Only Party" yang diasumsikan hadir pada paruh kedua monarki - yang menurut Smith belum tentu kelompok ini berasal dari 
nabi-nabi propetik minoritas, sebaliknya dipercaya gerakan ini muncul dari masyarakat itu sendiri. Jadi monoteisme yang hadir kemudian; entah pada era monarki atau pembuangan, telah didahului dengan hadirnya monolatri berdasarkan ide convergence dan differentiation.

Pada bagian selanjutnya, Smith menekankan tiga level pengembangan agama dan kultur di Israel dalam hubungannya dengan convergence yang bermuara pada monoteisme. Pertama: convergence merefleksikan agama dan sistem kepercayaan Israel sebagai warisan Kanaan; yang termasuk dalam kategori ini adalah El, Baal, Aserah, simbol-simbol serta julukan mereka, kuil-kuilm Bamot, dan liturgi penyembahan terhadap orang mati. Kedua: adalah bagaimana Israel berbagi konsep dengan bangsa sekitarnya: hadirnya allah nasional yang baru, hadirnya pendamping alllah, dan jumlah kecil ilah yang bisa dihubungkan dengan kultur Semit Barat. Ketiga: ada karakteristik spesifik dalam kultur Israel; seperti hadirnya allah baru, Yahweh, tradisi-tradisi terpisah di Israel dan Yehuda, dan menurunnya antropomopisme. Tradisi biblikal yang berhubungan dengan pemisahan dan pengembangan agama Israel terdapat dalam poin ke tiga; terutama yang berhubungan denganpenekanan pada Israel yang di luar tanah perjanjian, pemberian Taurat, dan terciptanya ikatan perjanjian Sinai.

Pada akhirnya Simth mengakui walaupun alasan terjadinya "convergence" di Israel tidak jelas, namun jalur kompleks dari convergence menuju monolatri dan monoteisme dapat diikuti. Bagi Smith, perkembangan monolatri dan monoteisme Israel sanggat mengandalkan proses evolusi dan revolusi dalam konsep religius. Monolatri bertumbuh di masa awal, terbatas dalam lingkup politeisme Israel dan kemudian tidak berlanjut. Kemudian pengakuan terhadap satu ilah menjadi tonggak perubahan dari era Hakim-Hakim ke era monarki. Revolusionari terjadi ketika munculnya proses differentiation seperti penggantian figur dan peran fungsi Baal dari kultik nasional Israel yang membedakan mereka dengan bangsa sekelilingnya. Dan ketika Israel bertekad mempertahankan hadirnya satu ilah, maka mereka dengan jelas memberikan jarak pembeda dengan negara tetangganya.

\section{Tanggapan}

Smith berargumentasi terdapat tiga tendensi utama dalam sejarah agama Israel. Ada yang disebut convergence dari karekteristik allah-allah seperti El, Baal, dan Aserah ke dalam figur Yahweh. Yang ke dua adalah differentiation figur Baal dan Aserah yang berbeda dari Yahweh. Dan pada akhirnya terdapat peran monarki dalam penerimaan luas dari beragam ilah dan simbol yang diasosiasikan dengan Yahweh yang semua ini kemudian ditolak pada era monarki di bawah pemerintahan Yosia. Bagi Smith, El bukanlah ancaman Israel. Ilah ini hanya mengalami asimilasi dengan Yahweh pada millennium pertama yang dibuktikan dengan munculnya nama Yahweh-El. Baal dinyatakan merupakan ancaman mulai abab 9 SM dan seterusnya, yang digambarkan dalam narasi Ahab dan Jesebel. Namun demikian, karakter-karakter Baal seperti allah 
badai diadopsi dan dikenakan kepada Yahweh. Demikian pula Aserah, figur ini direduksi ke dalam kultus Yahweh. Hal ini dapat terlihat dalam karakter feminin yang dimiliki Yahweh serta personifikasi hikmat yang mulanya menjadi ciri khas Aserah (female). Yahweh juga sering dihubungkan dengan penyembahan matahari yang kemudian hari dikenal dengan simbol matahari dalam bentuk sayap dan matahari yang menjadi simbol resmi monarki di Yehuda. Kultus orang mati secara luas mendapat toleransi, dan hanya necromancy yang sering mendapat penolakan. Semua ini hanya bertahan sampai pada abad ke 8, atau ketika era literature propetik muncul. Karya Smith yang lebih menekankan proses evolusi dalam penekanan kepada "asimilasi" ini, ternyata banyak mempergunakan material era jaman perunggu dan jaman besi, juga materi klasik lainnya. Dengan ini ia memberikan peluang seluas-luasnya terhadap interpretasi kritis. Penggabungan semua materi dalam presentasi yang meyakinkan ini sangat mungkin sulit mencari kesalahannya. Namun demikian tetap terbuka ruang untuk pertanyaan mengenai apakan pembaca akan mengikuti pola evolusionis yang diusungnya ini? Kelebihan lain dari karya Smith ini adalah kemampuannya untuk mengumpulkan beragam sumber penelitian serta dari beragam tempat, waktu, dan genre yang dipergunakan untuk merekonstruksi material analisis ini. Sehingga di satu sisi, perbedaan-perbedaan yang ada dapat diukur dengan cermat. Dan apabila terdapat saksi yang banyak, maka aspek persuasive dapat dikedepankan. Kekurangan yang ada mungkin dari sumber-sumber yang bersifat fragmentary dan interpretasi yang terkadang tidak meyakinkan. Jadi apa yang diperoleh secara komprehensif, seringkali lenyap ketika ditelaah secara individual.

\section{Daftar Pustaka}

Mark S. Smith. The Early History of God: Yahweh and the Other Deities in Ancient Israel. Edited by Patrick D. Miller. 2nd ed. Grand Rapids: Eerdmans; Dearborn, Mich.: Dove, 2002. 